\title{
Mobiluncus curtisii
}

National Cancer Institute

\section{Source}

National Cancer Institute. Mobiluncus curtisii. NCI Thesaurus. Code C86518.

A species of anaerobic, Gram positive, curved rod shaped bacterium assigned to the phylum Actinobacteria. This species is motile by one to six flagella that originate from the same spot on each cell and is oxidase, indole and catalase negative. M. curtisii is found in the vaginal tract and is pathogenic, being a causative agent of bacterial vag inosis. 